\title{
Avaliação do custo-efetividade de um aplicativo de smartphone como ferramenta auxiliar na triagem clínica de doadores de sangue
}

Recebido: 28 jan 2019 Aceito: 10 fev 2019

Autor de correspondência: ms.hematologia@live.com

Conflito de interesses: Os autores declaram não haver nenhum interesse profissional ou pessoal que possa gerar conflito de interesses em relação a este manuscrito.

\footnotetext{
${ }^{(1)}$ Instituto de Hematologia e Hemoterapia Arthur de Siqueira Cavalcante - HEMORIO, Rio de Janeiro, RJ, Brasil.
}

\section{Resumo}

Os smartphones têm sido utilizados na área da Medicina através de aplicativos que avaliam a saúde de seus usuários. A popularização destes aparelhos com internet $3 \mathrm{G}$ e $4 \mathrm{G}$ (terceira e quarta geração) permitiu interatividade em até $24 \mathrm{~h}$ através de aplicações; entretanto, aplicativos destinados à hemoterapia em sua maioria, são exclusivos à captação de doadores de sangue e fornecem informações limitadas sobre as causas de inaptidão clínica que podem afastar o doador por tempo determinado ou definitivamente. Muitas destas causas seriam evitadas com informações prévia destas condições de impedimento, considerando que boa parte dos doadores de sangue descobrem alguma doença ou alteração fisiológica após a doação e assim o descarte de bolsas de sangue tem sido frequente na história da hemoterapia. Com foco de manter os aspectos de proteção ao doador e ao receptor do sangue, o exame clínico é responsável pelo elevado custo financeiro envolvendo a segurança transfusional. Um dos fatores que contribui para o descarte sorológico é a frequente troca na marca dos testes de triagem sorológicas utilizadas, em função das normas de licitação a que estão subordinados os bancos de sangue da rede pública para a comprar produtos e selecionar novas tecnologias. Segundo a comissão nacional de incorporação de tecnologia no SUS (CONITEC), todas as tecnologias devem apresentar provas científicas de eficácia e segurança para aprovação e consideradas por cinco tipos de análise econômica: custo-efetividade; custoutilidade; custo benefício; custo-minimização; e impacto orçamentário e em cada processo de decisão para implantação de novas tecnologias, sejam elas inovadoras ou de aprimoramento do que já funciona, apesar das margens de erro. As tecnologias focadas ao usuário simples e de fácil acesso, não precisam de suporte e períodos de capacitação de equipe multiprofissionais evitando prejuízo para os sistemas de saúde já que o conceito de atendimento integral preconizado é um dos temas que mais despertam polêmica no contexto das avaliações da utilização das novas tecnologias, pois declara o uso de todas as tecnologias para todas as pessoas, o que geralmente não se aplica aos sistemas de saúde, o que torna uma tecnologia gratuita para os usuários a ferramenta que raciona o tempo 
e os recursos desperdiçados para investimento em outras áreas necessitadas nos hemocentros, principalmente onde o estudo foi realizado. O processo de trabalho na triagem clínica acontece a partir dos encontros em fluxos operativos, políticos, comunicacionais, simbólicos e subjetivos, formando uma intrincada rede de relações e, a partir dela, os produtos referentes ao cuidado ganham materialidade e condições de consumo; esta fase, constitui-se de uma entrevista, avaliação da história clínica e epidemiológica, do estado de saúde, dos hábitos e comportamentos do candidato à doação, para determinar se ele está apto a doar sangue sem que haja prejuízo à sua saúde e a do receptor. As empresas informatizadas apresentaram bons resultados e buscam melhorar em seus processos regularmente, demonstrando também o aumento da produtividade, melhoria da qualidade de serviço e maior estímulo para profissionais da área. Objetivo: mapear as principais causas de inaptidão clínica definir medidas preventivas através de um aplicativo para otimização e qualidade do atendimento na triagem clínica a fim de economizar recursos materiais de coleta e produção de bolsas de sangue e hemoderivados. Métodos: foram acessados dados do Instituto Estadual de Hematologia Arthur de Siqueira Cavalcante - HEMORIO, para levantamento das causas de inaptidão clínica entre os candidatos à doação de sangue, no período de 01/01/2018 a 27/08/2018 a fim de selecionar um template compatível com os sistemas Android, iOS e Windows para o desenvolvimento de um aplicativo correspondente a triagem clínica presencial. Não houve necessidade de submissão ao Comitê de Ética me Pesquisa - CEP. Resultados: o índice de aptidão dos candidatos a doação de sangue foi de apenas $78,40 \%$, dentre os 70.329 que compareceram a triagem clínica, advertindo-nos para os 21,60\% de doadores inaptos, no período de 01/08/2018 à $27 / 08 / 2018$. As principais causas de inaptidão clínica de candidatos a doação de sangue encontradas neste estudo são anemia (20,89\%), uso de medicamentos (6,99\%), tatuagem/acupuntura/piercing exceto cavidade oral e região genital (5,57\%), estado gripal (5,55\%), situação de risco/múltiplos parceiros sexuais $(5,20 \%)$, sexo sem preservativo $(5,16 \%)$, vacina recente $(4,52 \%)$, endoscopia digestiva/colonoscopia/processo endoscópico (4,23\%), doença cardíaca (2,89\%), processos infecciosos $(2,43 \%)$, peso insuficiente $(2,42 \%)$, hipotensão arterial $(1,97 \%)$, falta de repouso $(1,83 \%)$, hipertensão arterial (181\%), peso superior a $140 / \mathrm{kg}(1,63 \%)$, área endêmica de malária (1,48\%), doença sexualmente transmissível (1,45\%), piercing na cavidade oral e região genital (1,43\%), cirurgia $(1,36 \%)$, homem que mantém ou manteve relação sexual com outro homem $(1,32 \%)$, alergias respiratórias $(1,22 \%)$, hipertensão arterial sem tratamento $(1,22 \%)$, poliglobulia $(1,18 \%)$, doença endócrina (1,09\%). Conclusões: um aplicativo elucidativo, com uma dinâmica semelhante ou transcendente a entrevista clínica teria um efeito positivo, pois diminuiria $75,33 \%$ das inaptidões encontradas e solucionaria fatores não aferidos, como a exigência de documento com foto e traria grande impacto na redução de descarte de materiais. Estudos futuros com o aplicativo de smartphone desenvolvido associado a sistemas simples e gratuitos que poderiam ser utilizados em hemocentros públicos e 
privados, são necessários para a melhoria do atendimento aos candidatos, redução do tempo de espera e suspeita de omissão na etapa de triagem clínica.

Descritores: Medicina Transfusional; Aplicativos Móveis; Tecnologia, Inovação. 